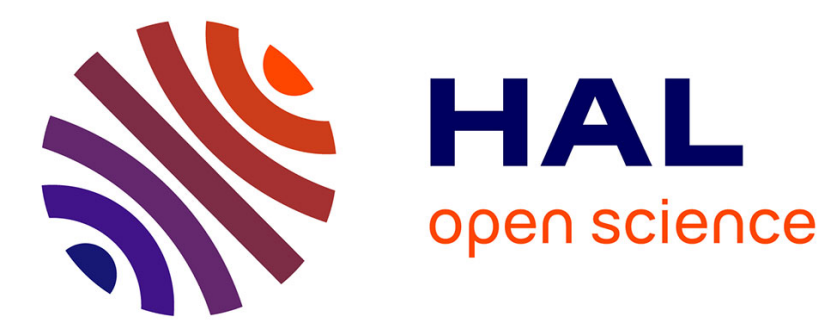

\title{
How do lobbies and NGOs try to influence dietary behaviour?
}

\author{
Caroline Orset Orset, Marco Monnier
}

\section{To cite this version:}

Caroline Orset Orset, Marco Monnier. How do lobbies and NGOs try to influence dietary behaviour?. Review of Agricultural, Food and Environmental Studies, In press, 20 p. 10.1007/s41130-020-00114y . hal-02891112

\section{HAL Id: hal-02891112 \\ https://hal.science/hal-02891112}

Submitted on 6 Jul 2020

HAL is a multi-disciplinary open access archive for the deposit and dissemination of scientific research documents, whether they are published or not. The documents may come from teaching and research institutions in France or abroad, or from public or private research centers.
L'archive ouverte pluridisciplinaire HAL, est destinée au dépôt et à la diffusion de documents scientifiques de niveau recherche, publiés ou non, émanant des établissements d'enseignement et de recherche français ou étrangers, des laboratoires publics ou privés.

\section{다(1)(2)}

Distributed under a Creative Commons Attribution - ShareAlikel 4.0 International 


\title{
How do lobbies and NGOs try to influence dietary
}

\author{
behaviour?*
}

\author{
Caroline Orset ${ }^{\dagger}$ and Marco Monnier!
}

\begin{abstract}
Nowadays, the dietary behaviour of consumers is an economic and societal concern. Affecting this behaviour remains consequently a challenge for the groups of influences. In this article, we focus on the influence that lobbies and NGOs can exert on the dietary behaviour of consumers. We provide a comprehensive overview and we link the theoretical and empirical economic literature to the influence strategies of these two actors. To be specific, three strategies are exposed and examined: information campaigns, labels and also the dissemination of misinformation. We conclude with a discussion on the consequences and the limits of those influence strategies on certain food sectors (meat, milk and sweet products).
\end{abstract}

Keywords: Environment, Food consumption, Health, Label, Lobby, Misinformation, NGO.

JEL Classification: D1, D83, L31, L66.

*The authors conducted this research as part of project DIETPLUS ANR17-CE21-0003 funded by the French National Research Agency (ANR). The views expressed in this article are the sole responsibility of the author and do not necessarily reflect those of its institution. The traditional disclaimer applies. We declare that we have no relevant or material financial interests that relate to the research described in this paper.

†Economie Publique, AgroParistech, INRAe, Université Paris-Saclay - caroline.orset@agroparistech.fr, 16 rue Claude Bernard, 75005 Paris.

${ }^{\ddagger}$ Research assistant AgroParisTech, marcomonnier09@gmail.com 


\section{Introduction}

Currently, the diet is at the heart of consumer concerns. Indeed, for instance in France, according to the report of the 2017 Observatory of Ethics in Food, $82 \%$ of people devote more attention to their diet compared to three years. Quality continues to be a factor of choice but other factors like health and the environment appear just as important.

Consider the example of meat consumption. Reducing the consumption of meat in favour of vegetables is at the centre of a heated debate. World meat consumption has increased dramatically in recent decades. According to the Food and Agriculture Organization of the United Nations (FAO), this represented 323 million tons of meat eaten in 2017 against 67 million in 1957, therefore five times more in 60 years. According to forecasts, this trend is expected to continue to increase by $15 \%$ by 2028 . The rapid growth of the world population, which had grown from about 3 billion inhabitants in 1960 to more than 7.5 billion in 2017 leads to this increase. Furthermore, according to FAO data, an average of $43 \mathrm{~kg}$ of meat per capita was consumed worldwide in 2014 for only $23 \mathrm{~kg}$ in 1961, therefore global meat consumption which has almost doubled in about 50 years. However, per capita meat consumption has evolved differently in various regions of the world and varies between $10 \mathrm{~kg}$ per capita in developing countries to $80 \mathrm{~kg}$ in developed countries. It has increased significantly in countries that have experienced significant economic transition like China, the Philippines, and Vietnam. According to the United States Department of Agriculture (USDA), in 2017, in the United States, average meat consumption is estimated at around $98 \mathrm{~kg}$ per capita while it was at round $90 \mathrm{~kg}$ in 2007. Then, an increase of almost $9 \%$ in 20 years. On the other side, according to data published by FranceAgriMer, the annual French person meat consumption decreased from $93.6 \mathrm{~kg}$ in 1998 to $87.5 \mathrm{~kg}$ of meat in 2018. Therefore, what influences the increase or decrease in meat consumption?

Meat consumption produces beneficial effects on health, but in addition represents risks. Indeed, meat constitutes a significant source of protein, vitamins and minerals that are essential for health. However, some epidemiological studies highlight the positive association between the consumption of meat ( $\operatorname{red}^{1}$ and processed ${ }^{2}$ meat) with the

\footnotetext{
${ }^{1}$ According to the World Health Organization (WHO), red meat refers to beef, veal, pork, lamb, mutton, horse, and goat.

${ }^{2}$ According to the WHO, processed meat refers to all processes to enhance flavour or improve preser-
} 
mortality rate, the onset of disease including type 2 diabetes, cardiovascular disease and colorectal cancer, for both men and women. For example, Chan et al. (2011) found a significant $17 \%$ increase in colorectal cancer risk per 100 grams of red meat eaten per day. They also discovered that this same risk increased significantly by $18 \%$ for 50 grams of processed meats consumed per day. Pan et al. (2012) observed a significant increase of $18 \%$ (respectively $21 \%$ ) in cardiovascular mortality for 84 grams of red meat (respectively processed meat) consumed per day. According to Battaglia Richi et al. (2015), the reasons for the side effects of red meat on the onset of diabetes or certain forms of cancer have been unclarified with certainty yet. However, they noticed that processed meat would promote the development of diabetes because of other ingredients such as curing salt or other salts as preservatives, and nitrites they contain. Because of these evidences, WHO classified red meat in group 2A, that is, probably carcinogenic to humans, and also classified processed meat in group 1 , that is, carcinogenic to humans. ${ }^{3}$

On the other hand, some studies analysed the health aspects of vegetarianism and veganism. According to Huang et al. (2012), vegetarians are less likely to die from cardiovascular disease or certain types of cancer than carnivorous individuals. In fact, their risk of death from coronary heart disease is $29 \%$ lower than that of carnivores. In addition, they are also 18\% less likely to develop cancer. However, during a diet without meat, it is necessary to have a sufficient intake of protein and micronutrients like iron and zinc to avoid any deficiency. Indeed, heme iron from meat is much better absorbed than non-heme iron from plant foods, and the meat is the type of food delivering the greatest contribution of iron. According to Craig (2009) vegans also develop the problem of the vitamin B12 because they do not consume any animal products (neither meat, nor fish, nor eggs, nor dairy products). Children by vegan mothers who were not taking enough vitamin B12 may have severe neurological legions (von Schenck et al. 1997; Guez et al. 2012). Therefore, it remains challenging to assess whether it is better for health to eat or not to consume meat.

In addition, through a scientific consensus on the damage that meat consumption causes to environment, many people consider there is no link between their food consumption and the environmental impact they may have in the process of food production (Grunert et al. 2014). Yet, according to Godfray et al. (2018), meat produces more greenvation.

\footnotetext{
${ }^{3}$ For more details see: https://www.who.int/features/qa/cancer-red-meat/en/.
} 
house gas (GHG) emissions than plant-based foods because energy is consumed at every level of the agricultural network. To be able to sustain the demand, producers devastated the forests for creating pasture and arable land to feed the animals. Herrero et al. (2011) and Gerber et al. (2013) noticed that meat production constitutes a direct source of major GHGs like carbon dioxide $\left(\mathrm{CO}_{2}\right)$, methane and nitrous oxide $\left(\mathrm{N}_{2} \mathrm{O}\right)$. The total livestock supply chain contributes approximately $15 \%$ or 7.1 Gigatonnes of carbon dioxide equivalent $\left(\mathrm{CO}_{2}\right.$-eq) per annum of anthropogenic GHGs. Moreover, animal production imposes a significant demand for natural resource water and in this way aggravates soil erosion, therefore causing more GHGs indirectly (Hoekstra and Mekonnen, 2012). Current trends in meat production and consumption are now considered unsustainable. According to the European Environmental Agency (2015), food consumption accounts for one-third of the total environmental impact of individuals. The food chain produces GHG emissions at all stages, from operations to waste disposal, through industry and distribution. Indeed, consumption represents the ultimate step of the production process. Thereby, food consumption is responsible for GHG emissions in a not-insignificant proportion. According to Lombardi et al. (2017), changing the food consumption of individuals can produce a significant impact in reducing GHG emissions. Indeed, influencing consumer behaviour towards a more sustainable and climate-neutral purchasing model could be an effective option for sustainably reducing GHG emissions.

In view of recent analyses on the health and environmental impacts of meat consumption, it seems evident that consumer dietary behaviour pattern presents a considerable challenge. Like so, it is intriguing to analyse which factors affect it. The influence of lobbies $^{4}$ and non-governmental organisations $(\mathrm{NGOs})^{5}$ on public policies has already been widely discussed in the literature (Bomberg 2007; Bramoullé and Orset 2018 ; Dur and De Bievre 2007; Klüver et al. 2015 ; Saloojee and Dagli 2000 ; Strömberg 2001). Their influence has been illustrated in government and international decisions on climate change or on tobacco control campaigns. But it does not on the individual's dietary consumption. Therefore, how do lobbies and NGOs influence the consumers' food choices?

\footnotetext{
${ }^{4}$ Lobbies are interest groups that try to influence laws, regulations, standards setting, decisions... to promote their own interests.

${ }^{5}$ NGOs are non-profit and are organisations of civil society, of public interest or of a humanitarian nature, which do not depend on a state or an international institution. An NGO decides autonomously on the actions it engages. Its resources come from public or private funds.
} 
To respond this question, this article will focus in section 1 on the various interests of lobbies and NGOs for dietary behaviour of consumers. Next, it will develop the alternative strategies of influence (information campaigns in section 2, labelling in section 3, and misinformation in section 4) that these two actors can exercise on the consumers. Finally, section 5 discusses about the impacts of the lobbies and NGOs' influence on the personal choices of food consumption and on their limits.

\section{Interests of lobbies and NGOs for the dietary be- haviour of consumers}

In itself, a lobby is not absolutely dreadful because it offers the opportunity for all market actors to communicate, to be represented and to achieve their point of view. First, the lobby of consumers, operating essentially in the form of an association, aims to inform, represent and help consumers in the event of a dispute. This lobby expresses no interest in governing the dietary behaviour of consumers. These associations also put pressure on public authorities and form a substantial opposing power for corporate lobbyists.

Second, the food industry is the main lobby of the food market. The food industry transforms into foodstuffs principally intended for human consumption, plant and animal productions derived from agriculture, livestock farming or fishing. In some countries, the food sector is the leading industrial sector in terms of turnover and employment. This is, for example, the case of France. In 2017, the 17,647 companies in the sector generated a turnover of 180 billion euros and employed 429,079 people spread throughout the national territory. Food industries generated 4,491 new jobs in 2017. Food represents a significant business sector since it processes $70 \%$ of French agricultural production. The sector gains, in addition, a valuable support for the country's trade balance: in 2017, it generated a trade surplus of 7.6 billion euros. ${ }^{6}$ At the European level, it ranks second behind Germany (INSEE classification in 2015).

The revenue of food industries is substantial, it can be comparable to the GDP of some countries. For example, if we considered the ten most considerable revenues for this sector in 2015: Nestle AG with 92 billion dollars, PepsiCo, Inc. with 63 billion dollars, JBS SA

\footnotetext{
${ }^{6}$ For more details: see https://www.ania.net/
} 
with 48 billion dollars, The Coca-Cola Company with 44 billion dollars, AB InBev with 43 billion dollars, Tyson Fodds Inc. with 41 billion dollars, Mondelez International Inc. with 30 billion dollars, Kraft Heinz with 27 billion dollars, Archer Daniels Midlands with 25 billion dollars and Danone with 23 billion dollars, this represents 436 billion revenue which is almost equivalent to the GDP of the Thailand (401 billion dollars in 2015), Belgium (456 billion dollars in 2015) and Poland (478 billion dollars in 2015). ${ }^{7}$ Faced with such a revenue opportunity, controlling and guiding consumer demand becomes an inevitable goal for these firms.

Furthermore, to ensure the competitiveness and their development, food industries must constantly innovate. Food industries innovate more than other sectors $(69 \%$ versus $60 \%$ for other manufacturing industries and $48 \%$ for all sectors). However, consumer behaviour in food is changing faster and faster and innovation is costly. For instance, in 2014, the innovation expense for the food industry sector represented $1.3 \%$ of the sector revenue (Agreste, 2018). Hence, attracting and convincing consumers becomes a crucial issue for these firms.

Another actor carries out an important role in the sphere of influence of the food market, the non-governmental organisations (NGOs). An NGO represents the voice of citizen groups. In general, NGOs look for identifying and sanctioning illegal practices through legal action. They try to raise awareness of the damage that the consumption of certain foods causes to the environment or to health. They are also intended to feed the public debate.

In the food sectors, the NGOs are extremely active in combating the negative impacts of food consumption on human health, the environment and animal welfare. For instance, Foodwatch fights for safe, healthy and affordable food for all. Their goal is to defend consumers' right to a food that does not harm people's health or the environment. She considers herself to be a counterweight to the power of the food industry. Besides, with the ambition to fight against climate change and the environment preservation, the Climate Action Network (Réseau action climat), Greenpeace, the foundation Nature et l'Homme and the World Wildlife Fund (WWF) are also interested in dietary behaviour of consumers. These NGOs consider that the food industry sector as one of the sectors

\footnotetext{
${ }^{7}$ For more details see: http://agriculture.gouv.fr/Le-panorama-des-IAA and the Word Bank data for GDP.
} 
responsible for climate change (because of transport and energy production). They work to protect the environment and biodiversity. They fight against the food industries which do not practise ecological farming (elimination of pesticides, of the genetically modified organism and of toxic products). For that, the behaviour of the consumers, and like this the demand on non-ecological markets, are decisive. Brécard and Chiroleu-Assouline (2018) show that NGOs are willing to put pressure on non-ecological firms by promoting entry and certifying one of their competitors in the market, which is more aligned with the interests of the NGOs. Additionally, from the point of view of animal welfare, L214 also wants to influence the consumers' food behaviour. It collects information through filmed surveys in the field, the use of the testimony of certain professionals, the study of scientific or professional publications and the study of regulatory texts. Their goal is to reveal the reality of farms and slaughterhouses.

Therefore, like the food industry lobbies, influencing the dietary behaviour of consumers is a lever for NGOs to achieve their ambition. Indeed, enlisting as many consumers as possible for their cause allows them to make their message heard with other citizens and public authorities.

Moreover, these active groups of influence use methods of persuasion on consumers to achieve their goal. For this purpose, they write arguments, organise press campaigns, commission opinion polls or prepare meetings and colloquia to strengthen their legitimacy and visibility among citizens. In the following part, we discuss about the impact of these information campaigns on consumers' behaviour.

\section{Information campaigns}

Experimental and behavioural economics examined the impact of information campaigns on the dietary behaviour of consumers in various countries and for various foods. Lombardi et al. (2017) analysed with a choice experiments method how information and communications could affect the consumer's attitude towards fresh climate-neutral milk through a case study in Tuscany. The choice experiments method is a quantitative technique for eliciting individual preferences. It allows to uncover how individuals value selected attributes of a product by interrogating them to state their choice over different hypothetical alternatives. They found that communication makes in changing consumer 
attitude towards carbon-free products. Graham and Abrahamse (2017) next examined how individuals are motivated to change their meat consumption in a New Zealand sample. They analyse whether the information can influence the concerns about the impact of meat consumption on climate change as well as their attitude to dietary meat and their intention to reduce their consumption after that. They found that while providing information raises much more concern about the effects of meat consumption on the climate and significantly decreases the intentions of dietary meat, the behaviour of meat consumption does not change. Vainio et al. (2018) then analysed message framing and the refutation of incorrect information to persuade respondents to reduce their consumption of plant-based alternatives in a study conducted in Finland. They showed that only people believing relatively firmly in the negative health and climate effects of meat consumption changed behavioural intentions.

In addition, Castellari et al. (2018) assessed the impact of explanatory messages on health and the environment on consumers' willingness to pay (WTP) for meat products and plant substitutes in Italy. The WTP is defined as the maximum price at which a consumer will purchase one unit of a certain product, here meat and plant products. This approach allows analysing the consumers' preferences for the product, and therefore their consumption behaviour concerning this product. They showed that in the long term, information campaigns have an effect on the behaviour of meat consumption when these have been implemented as a solution to reduce meat consumption, in particular in addition to the tax on meat. Moreover, with the same approach, Marette (2018) assessed the impact of different messages on either the positive impact or the negative impact of fish consumption on health and sustainability on participants' WTP for canned fish in France. This study showed that, contrary to Bower et al. (2003) who found that all information providing a message about the positive impact on health of a product increase consumers' buying intention with respect to that product, only the messages describing the negative impacts lead to significant reductions in the WTP for tuna and sardines.

These studies explain the NGOs use of information campaigns providing messages on the adverse consequences that their diet behaviour generates on health and the environment to fight for the protection of biodiversity. Indeed, as Schultz (2002) suggested individuals will tend to modify their behaviour as soon as they understand they must change it. Therefore, Greenpeace emphasises the proliferation of green algae due to the 
intense demand for milk that is emerging in many intensive animal farming (like the thousand cow farm in Brittany, France). Greenpeace and WWF strongly communicate on the intense demand for soya from Brazil in France to feed livestock. This makes French consumers complicit with the fires ravaging the Amazon Rainforest. Besides, WWF fights against the production and use of palm oil. She informs consumers of their presence in many products of our ordinary life. It makes them aware of the drastic consequences for forests, wildlife populations, communities and climate change of consuming products made from palm oil. WWF is also extremely committed to the preservation of the oceans. She informs the consumers to raise awareness of overfishing and to convince them to adopt a more diversified and more reasoned consumption of seafood products (e.g. hake caught off the coast of Chile, blue fin tuna in the Mediterranean, sturgeon in the basin from the Volga or in the Amur River). Other NGOs, like Climate Action Network, propose measures to combat climate change through an ecological transition of the food system. Information campaigns, therefore, support the evolution of the diet (less meat and dairy products, more fruits and vegetables), a broader use of quality foods. In addition, Foodwatch informs consumers about the excesses of food industry lobbies to preserve a wholesome diet. ${ }^{8}$ She also denounces traps set for consumers like the promises of detoxification, anticancer, energy, slimming, anti-cholesterol... Further, by making consumers aware of the animal cause, through shocking reports such as intensive rabbit breeding and slaughter conditions, L214 encourages the consumers to restrain consuming animal products or at least to reduce their consumption.

To support their production and development, food industries also communicate with information campaigns on the merits of their product for consumption. Brands use social networks and advertising to enhance individual communication with consumers. Through media broadcasts, like films or reports the food industry lobbies counterbalance an uncomfortable piece of information that is at the origin of consumer caution. Van Wezemael et al. (2011) show that information on the production process of beef favours the acceptance of beef products by consumers. This explains many information campaigns and farm visits which are offered to consumers. For instance, Bledina organises for parents guided tours of the fields producing baby jars. In addition, the food industry lobbies,

\footnotetext{
${ }^{8}$ For more details: https://www.foodwatch.org/fr/actualites/2019/attention-toutes-les-promessessante-ne-sont-pas-bonnes-a-avaler/
} 
through educational kits and tattoos, also run information and awareness campaigns for children in school canteens. The meat and dairy sectors use this promotion channel a lot. For instance, in 2016, Interbev who defends the interests of the meat in France, has designed a kit distributed in 1,500 school canteens with posters representing animals in a meadow and on the plate, tattoos with slogans in the form of word play with the names of animals like veal and beef, a newspaper with a burger recipe and a video showing a farm and explaining the balanced diet. The dairy industry has also been in schools since 1982. The CNIEL, the National Interprofessional Center for the Dairy Economy, represents all the actors in the French dairy sector. With many slogans and marketing, she raises consumer awareness of dairy products. She distributes leaflets to children and teachers to praise and value the consumption of dairy products (calcium intake, fight against osteoporosis...) and stigmatises alternatives that do not contain dairy products. Therefore, as Mialon and Mialon (2017) show commercial interests of the dairy industry may impede public health policies and programs.

However, other channels of information dissemination than information campaigns can be just as useful. According to Samant and Seo (2016), information from the labels would not merely bring consumer knowledge about the products but would also impact both the acceptance of the product and the intention to buy it. Then, creating labels may represent a way for the food industry lobbies and NGOs to manage the dietary behaviour of consumers. We discuss about this strategy in the following part.

\section{Labelling}

A label is a specific mark created by a trade union and affixed to a product intended for sale. Its purpose is to facilitate the recognition of certain characteristics of the product. It represents an information tool for the consumer. For thirty years, consumers received information from public services or private initiatives on food packaging related to sustainable development. According to the website of Eco-label Index (2018), there were 463 eco-labels ${ }^{9}$ in 199 countries and 25 industry sectors in 2018. The European Commission

\footnotetext{
${ }^{9}$ Eco-labels guarantee an elevated level of the requirement in terms of limiting the negative impact of products and services on the environment and health, while maintaining their level of production performance.
} 
(2012) identified 129 public and private information programs on the sustainability of foods available at national and European level.

According to Cranage et al. (2004), consumers' perceptions of product quality and food security have an enormous psychological impact on their behaviour and decisions when shopping. This perception comes from the product information provided by labels and certifications or from their past consumption experiences with the product. ${ }^{10}$ Starting from this observation, Grunert and Wills (2007) demonstrated that individual interest and background knowledge of label claims persuade consumers to look out for the label claims while buying food products. The more consumers are exposed to label claims, the higher the chances of information indeed being perceived by them at a conscious or subconscious level. The consumers are attached to the information provided by labels because they find it useful and easy to understand. Subsequently, the understanding and liking of the label claims may be used in forcing choices with respect to produce evaluation and purchase behaviour. Aertsens et al. (2009) underlined that the most significant driver of purchasing organic foods is the perception that the organic dimension is safer, healthier, and better for the environment than regular processes for producing food.

However, many consumers do not capture the link between their consumption, and the negative impact of the food industry may have on the environment. This implies that despite their interest in preserving the environment, consumers do not modify their behaviour. This gap between mental attitude and behaviour exists partly since the information signal concerning the environmental impact of the product is often imperfect (Bleda and Valente, 2009; Schumacher, 2010; Thibert and Badami, 2011; Tobler et al., 2011; Vlaeminck et al., 2014). According to Vlaeminck et al. (2014), to be efficient for incentive the consumer to alter its behaviour, a food label should include more complete information with multiple criteria by describing various environmental impacts simultaneously rather than merely focusing on one. It should introduce a colour system on the label to make the interpretation of information more reachable to all. Further, it should improve the accessibility of the message for the consumers. Hence, with these three features, consumers would be encouraged to adopt an ecologically responsible diet. Yokessa and Marette (2019) also support this conclusion. For them, the challenge with eco-labels is to be able to convey unambiguous and understandable messages without

\footnotetext{
${ }^{10}$ The certification is framed by law. It is issued by an approved and independent certification body.
} 
compromising the complexity of environmental impacts. This growth in environmental problems poses problems of prioritisation when purchasing decisions for the environment, which reinforces the complexity of the labels.

Although for fair trade products, consumers are willing to pay a price premium of 10\% (De Pelsmacker et al. 2005; Kimura et al. 2010; Napolitano et al. 2008; Zander and Hamm 2010), as highlighted by Röös and Tjärnemo (2011) for carbon labelling and Grunert (2011) for eco-labels, the price perceived as high is the principal obstacle to the acquisition and use of sustainable products. Kimura et al. (2010) found that external social factors such as concern for peer reputations (Brécard et al., 2009, Sirieix, 2008) as well as intrinsic reasons for ethical issues could also motivate purchases with the Fair Trade label. Indeed, Vermeir and Verbeke (2006) suggested that increasing consumer involvement and increased social peer pressure can boost sustainable food consumption. Sirieix (2008) showed that in France, the choice of behaviours is directly linked to price, brand, quantity, use-by date and nutritional information and eco-labels. Hoogland et al. (2007) demonstrated that positive consumer reactions are generated by the inclusion of details on animal welfare standards for meat and dairy products. McEachern and Warnaby (2008) reinforced this idea and found that for purchasing decisions for products bearing the "Animal Welfare" label, knowledge of the labels and the standards on which they are based can carry out a significant role. Finally, in its experience, Marette (2018) observed a significant higher WTP for canned tuna sold with the Marine Stewardship Council (MSC) label compared to the WTP for canned tuna sold without a label. This positive premium for such a label indicating the sustainability of the fish shows that eco-labels can provide a considerable impact on consumers' preferences. This result is reinforced by Wijen and Chiroleu-Assouline (2019) who show the impact of the Marine Stewardship Council (MSC) label on sustainability transitions is generally broadly positive.

In the meat industry, labelling can be considered as a promotional tool that can carry out many diverse functions like the identification, the description or the promotion of a product (Kotler 1997), also like the differentiation from competitors by the assurance of a given quality level and the increase of the product attraction, or like advertising, modifying the product design, and even influencing consumer confidence about the product 
(Caswell and Mojduszka 1996). Indeed, labelling participates in the marketing process in the same way as other factors like the price, the brand or the availability of the product. Various studies captured the effect of labels on people's meat consumption choices. For instance, Wandel and Bugge (1997) studied the meat purchasing priorities in Norway. They showed that only $5 \%$ of consumers choose environmental concerns as an absolute priority for choosing to eat meat product. The price remains a significant concern for consumers' disincentive to buy meat products. In addition, according to Rimal (2005), the price, the income, the taste and the preferences represent the primary factors influencing the level of meat consumption in the United States. Rimal (2005) subsequently studied the consumption behaviour of individuals with respect to the diverse characteristics of meat labels by focusing on beef, poultry and fish. She found a substantial majority of people thinks that it is extremely important that meat labels contain information regarding nutrition, ingredients, health claims, and production processes, respectively. She additionally noted consumers who express an interest in nutrition and ingredient information on food labels frequently consume meat.

Font-i-Furnols and Guerrero (2014) also analysed the factors that can affect the preferences, the perception and the behaviour of consumers about the meat during their purchase since they represent the ultimate stage of the meat production chain. Their study is based on the fact that the meat consumption patterns of individuals depend on socio-economic factors, ethical and religious beliefs or tradition. In their model, they distinguished three factors impacting the behavioural tendencies of individuals in the meat sector, the psychological ones, the sensory ones, and the marketing ones whose labels are part of. They found that a clear labelling is an effective communication strategy that increases consumer confidence for the product labelled and particularly for the individual concerned about the health and nutritional problems of the products. This type of consumer would seek more information and are therefore more inclined to pay close attention and trust to the labels (Bernués et al., 2003).

It is commonly believed that food consumption and dietary choices can represent a valuable contribution to address current environmental challenges. Vlaeminck et al. (2014) conducted an experiment in a supermarket in Belgium to examine whether the fact that a food label effectively communicates the environmental impact of the product. They highlighted that the present labelling system generally favours only one significant 
factor for the environment at a time among, for example, the fact that a product is organic or not, its place of origin or its carbon emissions.

Next, Sörqvist et al. (2016) examined the effect of labelling an environmentally friendly and genetically modified for raisins in Sweden and the UK. According to them, these two characteristics are not mutually exclusive while consumers tend to think that the term "organic" means not genetically modified. In fact, an eco-friendly product is produced in an environmentally friendly way and beneficial to the health of farmers because using fewer pesticides and chemicals than conventional products. As for a genetically modified product, it means it has been transformed by biotechnology in order to increase its potential growth and resistance to parasites. They analysed the impact of a combination of an eco-label and a genetically modified label on the consumers' judgement regarding taste, health consequences and what they would be willing to pay. They found that the GMO label removes the psychological benefits of the eco-label.

Lombardi et al. (2017) also strengthened this result. They analysed how information and communication through food labels would increase transparency and the consumers' awareness of the consequences that their purchasing decisions may have on the climate. It would also reduce GHG emissions in a sustainable way by encouraging producers to manage climate-neutral production to produce decarbonized milk competitive with other milks. Their study showed there is a substitution effect between organic and carbon-free tags. The preference for carbon-free milk causes a decreasing demand for organic milk. The interaction between the two labels generates a competitive effect that can have an impact on the market share of organic foods and the sustainability of both consumption and production systems. Emberger-Klein and Menrad (2018) considered the effect of providing information from labels indicating the ecological sustainability of the product and the carbon emission label on the purchasing behaviour of consumers in supermarkets in Germany. They found that even if a carbon emission label is not decisive in the decision-making process, its presence is preferred to its absence. This study also highlights that the combination of relevant climate and carbon emissions information can influence consumers' food consumption decisions.

Crutchfield et al. (2001) analysed the potential benefits of the Food Safety and Inspection Service (FSIS) regulation of May 30, 2000, which depends upon nutritional labels for raw meat and poultry products. They found that consumers improve their 
food quality thanks to the nutritional information provided by the labels, which have the advantages of reducing the frequency of coronary heart disease, breast cancer, prostate cancer and colorectal, especially by reducing the intake of saturated fat and cholesterol. Cranage et al. (2004) showed by empirical observation that the information on the label concerning the nutritional quality of food leads to choices of repurchase compared to the absence of information on the label. According to Fernqvist and Ekelund (2014), the labels should additionally include other information, concerning the brand of the product, the beneficial effects on health, the origin, the production method and the ethics, for increasing the consumer's knowledge about the product. However, they mention the food industry lobby would try to slow down or prevent a clearer labelling of food products so as not to discredit their production.

Indeed, between 2008 and 2011, the Members of the European Parliament debated improving the labelling of food products to make it more legible to consumers. The project was called traffic lights. It consisted in affixing to the front of the packaging labels detailing the amount of sugar, fat (saturated) and salt. These quantities were directly represented by a red, orange or green colours pellet according to specific nutritional thresholds (Bancquart 2014). However, from Corporate Europe Observatory (2010), the Members of the European Parliament suggested the similar argument as the food industry, not to scare the consumer into consuming cold cuts to vote against this proposition.

This episode is reminiscent of another, more recent, at the time of discussions about the carrying out of Nutri-score in France (Julia and Hercberg, 2016; Mialon et al., 2018). This new signal helps to better inform consumers about the composition of processed foods: too much fat and too much sugar. But manufacturers asked that a study under real conditions of purchase be conducted by the Ministry of Health to compare this labelling with three others, the one of traffic lights, the one proposed by large retailers and the one proposed by the food industry. It is finally the Nutri-score that came into effect in 2017, despite persistent attempts by the food industry lobby to suppress it for four years. Nevertheless, this labelling remains optional (in application of a European regulation of 2011) and few notable groups are currently employing it.

All these studies confirming the importance of labels on perceptions of consumers well explain the reason why the food industry lobbies and the NGOs want to impose and choose their own labels on the food market. For instance, in France, the food industry 
lobby proposes labels like 'Elu produit de l'année', 'Bleu-Blanc-Cœur' and 'Saveur de l'année' which are marketed by private companies and self-proclaimed. The food industry lobby merely employs them in a marketing aim. But NGOs have also created labels. For example, the Aquaculture Stewardship Council was created by the World Wide Fund for Nature (WWF) and Friend of the Sea represents a project of the NGO Earth Island Institute. The objective of all these labels is to increase transparency along the food chain and inform the consumer in a way that can promote sustainable consumption. In addition, the public authorities may also introduce labels. For instance, in France, the public authorities via INAO (National Institute of Origin and Quality), certify six labels for food ( $\mathrm{AB}$ brand for organic farming, $\mathrm{AOC}$ for the controlled name of origin, $\mathrm{AOP}$ for protected designation of origin, IGP for Geographical Indication, STG for Traditional Specificity Guaranteed, and Label rouge) which are controlled by the Fraud Prevention Service or independent certification bodies.

However, the labels can be a source of confusion for the consumers. Grunert (2011) and Grunert et al. (2014) highlighted six barriers that limit the impact of eco-labels on consumer behaviour: non-perception of consumers regarding the objective of the label, information on the label disseminated in parallel with it, the wrong conclusion concerning the information on the label, the compromise between the eco-label and other alternative labels such as ethical labels for example, the lack of credibility of the label and the lack of motivation of the consumer during the purchase.

Wandel and Bugge (1997) also noted that failure to completely understand the meaning of eco-labels plays a role in disincentives to purchase products. As for Yokessa and Marette (2019), they highlighted the fact that trust and credibility in the labels are important factors in modifying consumers' behaviours. Indeed, the consumers cannot directly visualise the sustainable characteristics of the product, especially since the environmental impact of products is characteristic credence. Indeed, the consumers cannot be absolutely confident of sustainable attributes even after consumption of the product. If the consumers do not trust the label, this one will not be efficient for changing the consumers' purchasing behaviours. This may be the case for a non-credible label.

Lenhart et al. (2008) underlined that technical label information also exerts very little effect on the purchasing behaviour as it is difficult for the consumer to comprehend it. Indeed, the labels tend to specify several environmental characteristics, notably the 
carbon footprint, greenhouse gas emissions, impact on forests, use of pesticides, water and energy consumption, alteration of biodiversity, fair trade, animal welfare or local production, which makes it illegible for the consumer.

Yokessa and Marette (2019) pointed out the proliferation of eco-labels also affects consumer confidence as many labels have similar sustainability characteristics. Actually, as underlined in Li and van’t Veld (2015), green markets frequently have an environmental program in competition with an industrial program. Consumers find it difficult to differentiate and determine which is the most effective. This proliferation of eco-labels in some situations limits the favourable effects that environmental information exerts on consumer behaviour, rather producing undesirable effects. Indeed, Brécard (2014), Comas Marti and Seifert (2012), Fischer and Lyon (2014), Grunert (2011), and Horne (2009) discussed that although increasing the number of sustainability labels can be seen as a success story, overselling these labels can cause a counterproductive effect by confusing consumers and limiting the use of these same labels. Moreover, even if competition between eco-labels can imply mergers or cooperation between NGOs and food industry lobbies that offer these ecolabel, according to Fischer and Lyon (2019), to comply with the standards indicated on these labels, cost considerations will dominate environmental protection.

Nevertheless, this vagueness can be an interesting lever for lobbies and NGOs to influence consumer behaviour. In the subsequent part, we discuss about the manipulation of information by lobbies and NGOs and its consequence on the dietary behaviour of consumers.

\section{Misinformation}

Traditional economic theory instructs us that a perfect information is a guarantee of market efficiency, but information remains a strategic element for those who own it and know how to treat it. The substantial risk for the consumer is that of manipulation.

It is not uncommon to see lobbies and NGOs commission opinion studies or make widely oriented reports, the purpose of which is to avoid constraints that run counter to their immediate interests. These studies sometimes take liberties with the scientific 
rigour that must prevail on such occasions.

It is a fact that the states are financing scientific research less and less. Conversely, firms possess more and more money and can finance a growing amount of research. In this way, if the studies risk undermining the image of the manufacturers who finance the studies, they do not publish them (Bramoullé and Orset, 2018). For example, Kearns et al. (2016) revealed that in 1967, the Sugar Research Foundation (SRF) industrial group funded studies through Project 226 to minimise the impact on heart disease. The manipulation was to blame the food fat in the minds of the public. In a statement, the Sugar Association acknowledged the mistakes of the SRF, but also defended accusing Kearns et al. (2016) to examine the role of saturated fats in heart disease at the expense of that of sugar. In support, Nestle (1993) and Nestle et al. (1998) also highlighted that the food industry continues exerting its influence in science. Indeed, in 2016, studies funded by candy manufacturers indicated that children dietary sweets weighed less than those who did not consume sweets. In addition, the New York Times revealed in 2015 that Coca Cola, leading producer of soda, had funded research to reduce the link between sugary drinks and obesity. Coca-Cola persevered and injected nearly seven million euro to minimise the impact of sweetened drinks on health. ${ }^{11}$ Furthermore, Coca-Cola reserves the right to prevent the publication of results that would not fit her affairs when funding studies (Steele et al. 2019). However, this type of behaviour is not recent. Let's recall the origin of the famous assertion: 'Breakfast is the most important meal of the day'. In 1917, Lenna F. Cooper, one of the two co-founders of the American Dietetic Association, defended this assertion by focusing on the health benefits of corns in Good Health, a health magazine edited by John Harvey Kellogg, the co-inventor of flaked cereals. This article allowed The Kellogg Company to generate many profits (according to the New York Times, in 2013, in 2013, the company earned approximately 10 billion in sales).

On the other side, the NGOs may make exaggerated statements. For example, Greenpeace published in 2019 misleading information about global warming. ${ }^{12}$ Greenpeace claimed that Arctic ice could disappear completely by 2030. Food is one of the factors contributing to global warming. Indeed, looking at the whole food chain, from the field to

\footnotetext{
${ }^{11}$ For more details see: https://www.foodwatch.org/fr/actualites/2019/coca-cola-continue-de-financerla-science-pour-vendre-ses-sodas-mais-ce-nest-pas-tout/

${ }^{12}$ For more details see: https://www.infowars.com/greenpeace-leader-admits-organization-put-outfake-global-warming-data/
} 
the fork, it is estimated that at least 30\% of total GHG emissions (IPCC 2014 Report). Food is like this a source of GHG emissions of the same magnitude as transport and housing. By overestimating, Greenpeace wanted to raise awareness of global warming. It was, in addition, a way to make consumers aware their diet should evolve towards a more sustainable diet.

Lobbies may also manipulate opinion leaders, like health professionals, to sow doubt among consumers. For example, food industries sponsor many congresses and acquire the right to organise sessions at these congresses. This was the case for McDonald's, which is an American fast-food chain and sells mostly beef, chicken and fish burgers and fries, breakfast menus, sodas, milkshakes and desserts, and Coca-Cola which sponsored the $6^{\text {th }}$ General Medicine Congress in 2012 in Nice (France). ${ }^{13}$ Despite the Ministry of Health's concerns about the significant increase in overweight and obesity in France related to the consumption of fat and sugar, these two large industrial groups were authorised to lead two sessions round the nutritional content of the meal. In addition, between 2010 and 2017, Coca-Cola also funded the Dietecom show, which reinforces the links between food manufacturers and health professionals on the theme of nutrition. By following their link with health professionals, food industries disseminate the most favourable information possible for their product to the consumer. The trust that exists between health professionals and consumers avoids a questioning of this information by the consumer. Health professionals serve as channels to influence the dietary behaviour of individuals.

Moreover, the food industry lobby can operate another channel, the participation in public health recommendation programs. For example, in France, the milk and meat industries are involved in the development of the National Health Nutrition Program (PNNS) and the food pyramid disseminated, at the expense of the State, to the entire French population. They serve as a legal basis for doctors, dietitians, nutritionists and other health professionals. Like so, the absence of legumes, nuts and seeds that can be a protein supply, and that of green leafy vegetables and broccoli for calcium intake in the PNNS, illustrate the influence of the dairy and meat industries about the messages in this program. Omitting foods that provide the health benefits that they promote remains a method of manipulating information from consumers. Through this channel, food lobbies

\footnotetext{
${ }^{13}$ For more details see: https://www.la-croix.com/Actualite/France/Le-lobby-agroalimentaire-etendson-influence-dans-le-monde-de-la-sante-_EP_-2012-06-21-821624
} 
may promote their products to consumers and their food. ${ }^{14}$

Finally, media (television, magazines, and newspapers), books, doctors, family, friends and firms that promote for instance, unproven health products (dietary supplements, weight loss products and herbs) are a source of misinformation. Scientific progress alone does not prevent or eliminate misinformation. In fact, Glaeser and Ujhelyi (2010) studied the possible regulation that the government could implement to respond to misleading advertising. They found it is recommended from a social welfare point of view to implement a tax or a quantity restriction on advertising if the advertising is always misleading. On the other hand, in addition to this misleading advertising, firms manage investments to improve the quality of their product, combining taxes or bans on advertising with other policies is recommended.

\section{Discussion}

Our study analyses why and how NGOs and food industry lobbies influence the dietary behaviour of consumers. The information campaigns and the labels are very often used as influence strategies. But, another strategy may be added, the dissemination of misleading information to preserve the production or support the ideas. Our study searches for raising awareness not only of consumers but also of public health advocates and policymakers that care should be taken to ensure that these influence strategies do not hamper environmental policies and national health programs.

In recent years, the meat and milk sectors illustrated the oppositions and manoeuvre of food industry lobbies and NGOs to engage consumers in their interests. For example, in these sectors in France, NGOs advocate for the animal cause, like L214, Compassion in World Farming (CIWF) and The Animal, Ethics and Science Foundation (LFDA), and other NGOs advocate for the preservation of the environment, like WWF or Greenpeace, to inform consumers about their cause. In fact, as Ellies-Oury et al. (2019) suggest, awareness of animal welfare and the environment is one of the factors behind the decline in meat sales (annual per capita meat consumption in France decreased by $6.5 \%$ between 1998 and 2018) and in milk sales (according to a CSA survey, decreased by $3.3 \%$ in 2018

\footnotetext{
${ }^{14}$ See Greenpeace $(2017,2019)$ for more details.
} 
compared to the previous year) in France. Faced with information on the conditions of slaughter and breeding and the rate of greenhouse gas emissions generated by these food industries, more and more French people want to eat in a responsible manner (Greenflex Study in 2016). Naturally, these images and the anti-milk's campaigns do not explain by themselves the reduction of the consumption of meat and milk in France, but they contribute to it. To limit this drop in consumption, food industry lobbies (like the Casino Group) are responding by introducing new labelling of their products on animal welfare with four rating levels, from A to D, and a gradation of green colour and a touch of grey, of which only the first three would ensure the welfare of animals is taken into account and significantly improved. They are also introducing new labels like Bleu-Blanc-Cœur, which promotes quality in the animal, environmental and human food sectors. They, in addition, do large transparency operations like visits to dairies and dairy farms. At the 2018 edition, more than 10,000 consumers participated.

Sales of sweet products also illustrate the power of the sugar lobby. Despite the multiple warnings on our health from the WHO which recommends curbing sugar consumption to combat obesity and diabetes, per capita consumption of sugary products has been stable for nearly 50 years in Europe. According to the organisation Corporate Europe Observatory, in 2018, the sugar lobby employs an average of 21.3 million euro annually to promote the interests of the sugar industry. The tactics of the sugar lobby are in every respect similar to those of the tobacco lobby (Oreskes and Conway 2011): to divert, even to convey contradictory scientific results, to sow doubt. For example, in France, the sugar lobby led the program EPODE (Together Prevent Childhood Obesity) with national education for parents and children to infiltrate and divert their product. But this is not the only one of their tactics to make consumers addicted to sugar. Moss (2013) reveals that international companies like Kraft, Coca-Cola, Lunchables, Frito-Lay, Nestlé, Oreos, Capri Sun and many others calculate the "bliss point" of sugary drinks that generate millions of sugar dependent consumers.

However, the tactics of firms to affect the dietary behaviours of consumers are undermined by new lifestyles in society. For example, the recent disaffection of consumers for breakfast, a prime time for milk consumption, is difficult to avoid for the dairy sector. In addition, food scandals also reduce the firms' influence. For instance, the Spanish cucumber in 2011 falsely accused of being contaminated by the bacterium E. coli has involved 
the firms to lose nearly 200 million euros per week. Also, the dairy group Lactalis in 2017 had been forced to suspend production in a French factory and recall all milk production from this factory following a scandal related to contamination by salmonella. This type of suspicion of the food industry can lead to a drop in difficult sales for the food lobby to control. In addition, in its report, INRA (2010) highlights various factors that it would be unusual to test to assess their impact on dietary behaviour. For example, estimating the impact on individual dietary behaviour of the social characteristics of the individual (income, age, gender), the place of home, the family and those round him, and the sensory factors (appearance, smell, texture and sound of food) would be clearly relevant. In this way, the weight of the influence of lobbies and NGOs on the dietary behaviour of consumers in relation to these factors is difficult to measure, but as we showed in our study, it is nevertheless genuine. For the moment, research seems to be hampered by the lack of databases made available to researchers. To eliminate this gap, it would be relevant to develop experimental and behavioural research in this area.

\section{References}

1. Aertsens, J., Verbeke, W., van Mondelaers, K., Huylenbroeck, G. (2009). Personal determinants of organic food consumption: a review. British Food Journal, 111, 1140-1167.

2. Agreste (2018). L'innovation dans les entreprises agroalimentaires. Les dossiers $n^{\circ} 42$.

3. Bancquart, R. (2014). Etiquetage des produits alimentaires : le poids des lobbies. http://www.allodocteurs.fr/actualite-sante-etiquetage-des-produits-alimentaires-lepoids-des-lobbies-12859.asp?1=1

4. Battaglia Richi, E., Baumer, B., Conrad, B., Darioli, R., Schmid, A., Keller, U. (2015). Health Risks Associated with Meat Consumption: A Review of Epidemiological Studies. Journal for Vitamin and Nutrition Research, 85, 70-78.

5. Bernués, A., Olaizola, A., Corcoran, K. (2003). Labelling information demanded by European consumers and relationships with purchasing motives, quality and safety of meat. Meat Science, 65, 1095-1106. 
6. Bleda, M., Valente, M. (2009). Graded eco-labels: A demand-oriented approach to reduce pollution. Technological Forecasting and Social Change, 76(4), 512-524.

7. Bomberg, E. (2007). Policy learning in an enlarged European Union: environmental NGOs and new policy instruments. Journal of European Public Policy, 14(2), 248268.

8. Bower, J.A., Saadat, M.A., Whitten, C. (2003). Effect of liking, information and consumer characteristics on purchase intention and willingness to pay more for a fat spread with a proven health benefit. Food Quality and Preference, 14(1), 65-74.

9. Bramoullé, Y., Orset, C. (2018). Manufacturing doubt. Journal of Environmental Economics and Management, $90: 119-133$.

10. Brécard, D., Hlaimi, B., Lucas, S., Perraudeau, Y., Salladare, F. (2009). Determinants of demand for green products: an application to eco-label demand for fish in Europe. Ecological Economics, 69, 115-125.

11. Brécard, D. (2014). Consumer confusion over the profusion of eco-labels: Lessons from a double differentiation model. Resource and Energy Economics, 37, 64-84.

12. Brécard, D., Chiroleu-Assouline, M. (2018). Component-free strategy of firms under pressure from the NGOs. Working Paper.

13. Castellari, E., Marette, S., Moro, D., et al. (2018). The Impact of Information on Willingness to Pay and Quantity Choices for Meat and Meat Substitute. Journal of Agricultural and Food Industrial Organization, 17(1).

14. Caswell, J.A., Mojduszka, E.M. (1996). Using informational labeling to influence the market for quality in food products. American Journal of Agricultural Economics, 78(4), 1248-1253.

15. Chan, D.S., Lau, R., Aune, D., Vieira, R., Greenwood, D.C., Kampman, E., Norat, T. (2011). Red and processed meat and colorectal cancer incidence: meta-analysis of prospective studies, PLoS One, 6(6).

16. Comas Marti, J.M., Seifert, R.W., 2012. Reviewing the Adoption of Eco-labels by Firms. Survey Report. 
17. Corporate Europe Observatory (2010). A Red Light for Consumer Information.

18. Craig, W.J. (2009). Health effects of vegan diets. The American Journal of Clinical Nutrition, 89(5), 1627-1633.

19. Cranage, D., Conklin, M.T., Lambert, C.U. (2004). Effect of Nutrition Information in Perceptions of Food Quality, Consumption Behavior and Purchase Intentions. Journal of Foodservice Business Research, 7, 43-61.

20. Crutchfield, S., Kuchler, F., Variyam, J.N. (2001). The economic benefits of nutrition labeling: a case study for fresh meat and poultry products. Journal of Consumer Policy, 24(2), 185-207.

21. De Pelsmacker, P., Driesen, L., Rayp, G. (2005). Do consumers care about ethics? Willingness to pay for fair-trade coffee. Journal of consumer affairs, 39, 363-385.

22. Dur, A., De Bievre, D. (2007). Inclusion without Influence? NGOs in European Trade Policy. Journal of Public Policy, 27(1), 79-101.

23. Ellies-Oury, M-P., Lee, A., Jacob, H., Hocquette, J-F. (2019) Meat consumption what French consumers feel about the quality of beef?. Italian Journal of Animal Science, 18(1), 646-656.

24. Emberger-Klein, A., Menrad, K. (2018). The effect of information provision on supermarket consumers' use of and preferences for carbon labels in Germany. Journal of Cleaner Production, 172, 253-263.

25. European Commission, 2012. Food Information Schemes, Labelling and Logos. Internal Document DG SANCO.

26. European Environmental agency (2015). European briefings: Consumption. SOER 2015

27. Fernqvist, F., Ekelund, L. (2014). Credence and the effect on consumer liking of food: A review. Food Quality and Preference, 32, 340-353.

28. Fischer, C., Lyon, T. P. (2014). Competing environmental labels. Journal of Economics and Management Strategy, 23(3), 692-716. 
29. Fischer, C., Lyon, T. P. (2019). A theory of multitier ecolabel competition. Journal of the Association of Environmental and Resource Economists, 6(3), 461-501.

30. Font-i-Furnols, M., Guerrero, L. (2014). Consumer preference, behaviour and perception about meat and meat products: An overview. Meat Science, 98(3), 361-371.

31. Gerber, P.J., Steinfeld, H., Henderson, B., Mottet, A., Opio, C., Dijkman, J., Falcucci, A., Tempio, G. (2013). Tackling climate change through livestock - A global assessment of emissions and mitigation opportunities. Food and Agriculture Organization of the United Nations (FAO), Rome.

32. Glaeser, E.L., Ujhelyi, G. (2010). Regulating misinformation. Journal of Public Economics, 94 (3-4).

33. Godfray, H.C.J., Aveyard, P., Garnett, T., Hall, J.W., Key, T.J., Lorimer, J., Pierrehumbert, R.T., Scarborough, P., Springmann, M., Jebb, S.A. (2018). Meat consumption, health, and the environment. Science, 361.

34. Graham, T., Abrahamse, W. (2017). Communicating the climate impacts of meat consumption: The effect of values and message framing. Global Environmental Change, 44, 98-108.

35. GreenPeace (2017). Viande et produits laitiers : l'État laisserait-il les lobbies contrôler l'assiette de nos enfants?

36. GreenPeace (2019). Cantines scolaires: les lobbies continuent de défendre leur biftech.

37. Grunert, K.G., Wills, J.M. (2007). A review of European research on consumer response to nutrition information on food labels. Journal of Public Health, 15.

38. Grunert, K.G. (2011). Sustainability in the food sector: a consumer behaviour perspective. International Journal on Food System Dynamics, 2, 207-218.

39. Grunert, K.G., Hieke, S., Wills, J. (2014). Sustainability labels on food products: Consumer motivation, understanding and use. Food Policy, 44, 177-189.

40. Guez, S., Chiarelli, G., Menni, F., Salera, S., Principi, N., Esposito, S. (2012). Severe vitamin B12 deficiency in an exclusively breastfed 5-month-old Italian infant 
born to a mother receiving multivitamin supplementation during pregnancy. $B M C$ Pediatrics, 24, 12-85.

41. Herrero, M., Gerber, P., Vellinga, T., Garnett, T., Leip, A., Opio, C., Westhoek, H., Thornton, P., Olesen, J., Hutchings, N., Montgomery, H., Soussana, J., Steinfeld, H., McAllister, T. (2011). Livestock and greenhouse gas emissions: The importance of getting the numbers right. Animal feed science and technology, Vol. 166-167, 779-782.

42. Hoekstra, A.Y., Mekonnen, M.M. (2012). The water footprint of humanity. PNAS, 109(9), 3232-3237.

43. Hoogland, C., de Boer, J., Boersema, J.J. (2007). Food and sustainability: do consumers recognize, understand and value on-package information on production standards?. Appetite, 49, 47-57.

44. Horne, R.E. (2009). Limits to labels: the role of eco-labels in the assessment of product sustainability and routes to sustainable consumption. International Journal of Consumer Studies, 33, 175-182.

45. Huang, T., Yang, B., Zheng, J., Li, G., Wahlqvist, M.L., Li, D. (2012). Cardiovascular disease mortality and cancer incidence in vegetarians: a meta-analysis and systematic review. Annals of Nutrition and Metabolism, 60(4), 233-40.

46. INRA (2010). Les comportements alimentaires. Quels en sont les déterminants? Quelles actions, pour quels effets ?. Rapport de l'expertise scientifique collective réalisée par l'INRA à la demande du ministère de l'Alimentation, de l'Agriculture et de la Pêche.

47. Julia, C., Hercberg, S. (2016). Research and lobbying conflicting on the issue of a front-of-pack nutrition labelling in France. Archives of Public Health, 74(1), 51.

48. Kearns, C.E., Schmidt, L.A., Glantz, S.A. (2016). Sugar Industry and Coronary Heart Disease Research: A Historical Analysis of Internal Industry Documents. JAMA Internal Medecine, 176(11), 1680-1685.

49. Kimura, A., Wadaa, Y., Kamada, A., Masuda, T., Okamoto, M., Goto, S., Tsuzuki, D., Cai, D., Oka, T., Ippeita, D. (2010). Interactive effects of carbon footprint 
information and its accessibility on value and subjective qualities of food products. Appetite, 55, 271-278.

50. Klüver, H., Mahoney, C., Opper, M. (2015). Framing in context: how interest groups employ framing to lobby the European Commission. Journal of European Public Policy, 22(4), 481-498.

51. Kotler, P. (1997). Marketing Management: Analysis, Planning, Implementation, and Control. 9th Edition, Prentice Hall, Upper Saddle River.

52. Lenhart, J., Kendall, P., Medeiros, L., Doorn, J., Schroeder, M., Sofos, J. (2008). Consumer Assessment of Safety and Date Labeling Statements on Ready-to-Eat Meat and Poultry Products Designed To Minimize Risk of Listeriosis. Journal of Food Protection, 71(1), 70-76.

53. Li, Y., van't Veld, K. (2015). Green, greener, greenest: Eco-label gradation and competition. Journal of environmental economics and management, 72, 164-176.

54. Lombardi, G.V., Berni, R., Rocchi, B. (2017). Environmental friendly food. Choice experiment to assess consumer's attitude toward "climate neutral" milk: the role of communication. Journal of Cleaner Production, 142, 257-262.

55. Marette, S. (2018). The Ambiguous Impact of Information Related to Fish Sustainability. Journal of Agricultural and Food Industrial Organization, 17(2).

56. McEachern, M., Warnaby, G. (2008). Exploring the relationship between consumer knowledge and purchase behaviour of value-based labels. International Journal of Consumer Studies, 32, 414-426.

57. Mialon, M. A. M., Mialon, J. (2017). Corporate political activity of the dairy industry in France: an analysis of publicly available information. Public health nutrition, 1-8.

58. Mialon, M., Julia, C., Hercberg, S. (2018). The policy dystopia model adapted to the food industry: the example of the Nutri-Score saga in France. World Nutrition, $9(2), 109-120$.

59. Moss, M. (2013). Salt, sugar, fat: How the food giants hooked us. Random House. 
60. Napolitano, F., Pacelli, C., Girolami, A., Braghieri, A. (2008). Effect of information about animal welfare on consumer willingness to pay for yogurt. Journal of Dairy Science, 91, 910-917.

61. Nestle, M. (1993). Food lobbies, the food pyramid, and US nutrition policy. International Journal of Health Services, 23(3), 483-496.

62. Nestle, M., Wing, R., Birch, L., DiSogra, L., Drewnowski, A., Middleton, S., Sigman-Grant, M., Sobal, J., Winston, M., Economos, C. (1998). Behavioral and social influences on food choice. Nutrition Reviews, 56(5).

63. Oreskes, N., Conway, E. M. (2011). Merchants of doubt: How a handful of scientists obscured the truth on issues from tobacco smoke to global warming. Bloomsbury Publishing USA.

64. Pan, A., Sun, Q., Bernstein, A.M., Schulze, M.B., Manson, J.E., Stampfer, M.J., Willett, W.C., Hu, F.B. (2012). Red meat consumption and mortality: results from 2 prospective cohort studies. Archives of internal medicine, 172(7), 555-63.

65. Rimal, A. (2005). Meat labels: consumer attitude and meat consumption pattern. International Journal of Consumer Studies, 29(1), 47-54.

66. Röös, E., Tjärnemo, H. (2011). Challenges of carbon labelling of food products: a consumer research perspective. British Food Journal, 113, 982-996.

67. Saloojee, Y., Dagli, E. (2000). Tobacco industry tactics for resisting public policy on health. Bulletin of the World Health Organization, 78(7).

68. Samant, S.S., Seo, H.S. (2016). Effects of label understanding level on consumers' visual attention toward sustainability and process-related label claims found on chicken meat products. Food Quality and Preference, 50, 48-56.

69. Schultz, P. (2002). Environmental Attitudes and Behaviors Across Cultures. Psychology and Culture, 8(1).

70. Schumacher, I. (2010). Eco-labeling, consumers' preferences and taxation. Ecological Economics, 69(11), 2202-2212. 
71. Sirieix, L., Grolleau, G., Schaer, B. (2008). Do consumers care about food miles? An empirical analysis in France. International Journal of Consumer Studies, 32, 508-515.

72. Sörqvist, P., Marsh, J. E., Holmgren, M., Hulme, R., Haga, A., Seager, P. B. (2016). Effects of labeling a product eco-friendly and genetically modified: A cross-cultural comparison for estimates of taste, willingness to pay and health consequences. Food Quality and Preference, 50, 65-70.

73. Steele, S., Ruskin, G., McKee, M., Stuckler, D. (2019). Always read the small print": a case study of commercial research funding, disclosure and agreements with Coca-Cola. Journal of Public Health Policy, 40(3), 273-285.

74. Strömberg, D. (2001). Mass media and public policy. European Economic Review, $45(4-6), 652-663$.

75. Thibert, J., Badami, M.G. (2011). Estimating and communicating food system impacts: A case study in Montreal, Quebec. Ecological Economics, 70(10), 18141821.

76. Tobler, C., Visschers, V.H., Siegrist, M. (2011). Eating green. Consumers' willingness to adopt ecological food consumption behaviours. Appetite, 57(3), 674-82.

77. Vainio, A., Irz, X., Hartikainen, H. (2018). How effective are messages and their characteristics in changing behavioural intentions to substitute plant-based foods for red meat? The mediating role of prior beliefs. Appetite, 125, 217-224.

78. Van Wezemael, L., Ueland, Ø., Verbeke, W. (2011). European consumer response to packaging technologies for improved beef safety. Meat Science, 89(1), 45-51.

79. Vermeir, I., Verbeke, W. (2006). Sustainable Food Consumption: Exploring the Consumer "Attitude - Behavioral Intention" Gap. Journal of Agricultural and Environmental Ethics, 19, 169-194.

80. Vlaeminck et al. (2014). Food labelling and eco-friendly consumption: Experimental evidence from the Belgian supermarket. Ecological Economics, 108, 180-190, 
81. von Schenck, U., Bender-Gotze, C., Koletzko, B. (1997). Persistence of neurological damage induced by dietary vitamin B-12 deficiency in infancy. Archives of disease in childhood, 77(2), 137-9.

82. Wandel, M., Bugge, A. (1997). Environmental concern in consumer evalutation of food quality. Food Quality and Preference, 8, 19-26.

83. Wijen, F., Chiroleu-Assouline, M. (2019). Controversy over voluntary environmental standards: A socioeconomic analysis of the Marine Stewardship Council. Organization and Environment, 32(2), 98-124.

84. Yokessa, M., Marette, S. (2019). A Review of Eco-labels and their Economic Impact. International Review of Environmental and Resource Economics, 13(1-2), 119-163.

85. Zander, K., Hamm, U. (2010). Consumer preferences for additional ethical attributes of organic food. Food Quality and Preference, 21, 495-503. 